\title{
LONG-TERM HYPOCHOLESTEROLEMIC EFFECT OF AMIDATED ALGINATE IN RATS
}

\author{
M. MAROUNEK $K^{1}, Z$. VOLEK $K^{1}$, T. TAUBNER ${ }^{1}$, \\ D. DUŠKOVÁ 1 , L. KALACHNIUK ${ }^{2}$ \\ ${ }^{1}$ Institute of Animal Science, Prague, Czech Republic; \\ e-mail:marounek.milan@vuzv.cz; \\ ${ }^{2}$ National University of Life and Environmental Sciences of Ukraine, Kyiv; \\ e-mail: kalachnyuk_liliya@nubip.edu.ua; lilkalachnyuk@gmail.com
}

The effect of octadecylamide of alginic acid on blood serum and hepatic cholesterol, and the faecal output of fat and sterols was examined in female rats fed diets containing cholesterol and palm fat at 10 and $50 \mathrm{~g} / \mathrm{kg}$, respectively for 10 weeks. Amidated alginate, supplied at 10 and $20 \mathrm{~g} / \mathrm{kg}$, significantly decreased serum cholesterol from 5.25 to 2.99 and $2.39 \mu \mathrm{mol} / \mathrm{ml}$, respectively, and decreased hepatic cholesterol from 30.7 to 12.3 and $9.4 \mu \mathrm{mol} / \mathrm{g}$, respectively. Amidated alginate increased the faecal output of fat and at higher dosing significantly decreased faecal output of bile acids. Faecal output of bile acids and hepatic cholesterol significantly correlated $(r=0.791 ; P<0.001)$. The results of the present experiment showed that hypocholesterolemic effect of amidated alginate persisted within 10 weeks of feeding.

Ke y w o rd s: cholesterol, blood serum, liver, faeces, fat, bile acids.

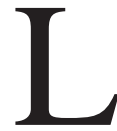

ipid-lowering agents are used with the purpose of amelioration of hyperlipoproteinaemia in order to prevent arterial disease. The clinical expression of arterial disease can be delayed by modifying plasma lipoproteins using systemic or non-systemic agents having hypocholesterolemic properties [1]. The latter hypocholesterolemic agents are anion-exchange resins which bind bile acids and increase their faecal excretion [2], and ezetimibe, a cholesterol absorption inhibitor that targets uptake at the jejunal enterocyte brush border [3]. An alternative to bile acid sequestrants are hydrophobic sorbents of neutral sterols: amidated pectin [4], amidated celluloses [5, 6], and amidated alginate [7, 8]. Amidated alginate is an effective cholesterol-lowering agent and sorbent of dietary fat. However, this suggests that the long-term intake of amidated alginate may cause the malabsorption of lipophilic micronutrients. The possibility of depletion of vitamins $\mathrm{K}$ and $\mathrm{D}$ during the long-term use of cholestyramine (a bile acid sequestrant) has been reported $[9,10]$.

In this study we tested a hypothesis that the hypocholesterolemic effect of amidated alginate would exist in rats within 10 weeks of feeding. The effect of amidated alginate on growth of rats, feed intake, and weight of liver and hepatic aminotransferases was examined as well. The present experiment extends our previous study in which amidated alginate was fed to rats for three weeks [7].

\section{Material and Methods}

Sodium alginate from brown algae was purchased from Sigma-Aldrich (a low-viscosity product no. A2158, Prague, Czech Republic). Alginic acid was prepared by washing sodium alginate with 1:1 mixture of ethanol and $4 \mathrm{M} \mathrm{HCl}$, pure ethanol, aceton, and dried in air. Alginic acid was esterified with methanol containing concentrated sulphuric acid. The methyl ester of alginic acid was aminodealkoxylated with n-octadecylamine [11]. The product of the reaction was filtered, washed with petroleum ether and pure ethanol. Its degree of amidation, calculated according to Taubner et al. [12] on basis of organic elemental analysis was $94.3 \%$. The rat diet ST-1 was supplied by Velaz Ltd. (Lysolaje, Czech Republic). Protected palm fat AkoFeed Gigant 60 was obtained from AarhusKarlshamn Sweden

(C) 2018 Marounek M. et al. This is an open-access article distributed under the terms of the Creative Commons Attribution License, which permits unrestricted use, distribution, and reproduction in any medium, provided the original author and source are credited. 
AB (Prague, Czech Republic). Sylon HTP kit (hexamethyldisilazane-trimethylchlorsilan-pyridine 3:1:9) was purchased from Supelco (Bellefonte, USA). Isolithocholic acid, 12-ketolithocholic acid, norcholic acid, $\alpha-, \beta$-, $\omega$-muricholic acids, and $\beta$-sitostanol were purchased from Steraloids Inc. (Newport, USA). Other sterols were supplied by Sigma-Aldrich (Prague, Czech Republic).

Twenty-eight female Wistar rats, approximately 6 weeks old, were used. The rats were housed individually in a temperature- and humidity-controlled room. The ST-1 rat diet was supplemented with palm fat and microcrystalline cellulose at 60 and $40 \mathrm{~g} / \mathrm{kg}$, respectively (basal diet, no. 1). After 4 weeks, the rats were randomly divided into 4 groups of 7 rats each. The diets no. 2, 3, 4 were supplemented with cholesterol at $10 \mathrm{~g} / \mathrm{kg}$, at the expense of palm fat. The diets no. 3, 4 were supplemented with amidated alginate at 10 and $20 \mathrm{~g} / \mathrm{kg}$, respectively, at the expense of cellulose (Table). Diets and water were available ad libitum. The experiment duration was 10 weeks, and then rats were sacrificed by decapitation, after anaesthesia by the inhalation of isofluran (Nicholas Piramal India Ltd., London, UK). The rats received $4 \mathrm{~g}$ of feed $4 \mathrm{~h}$ before they were sacrificed [13].

In the course of the experiment, body weight and feed intake were measured. The study was approved by the Ethics Committee of the Institute of Animal Science and the Central Commission for Animal Welfare of the Ministry of Agriculture of the Czech Republic.

Mixed blood samples were collected from each rat at the time of slaughter. The samples were taken into tubes without anticoagulant and allowed to stand for $30 \mathrm{~min}$. The sera were separated by centrifugation, stored at $+4{ }^{\circ} \mathrm{C}$, and analysed the subsequent day. The livers were excised and kept at $-40{ }^{\circ} \mathrm{C}$ until analysis. Faeces were collected during the last 5 days of the experiment, weighed, pooled and stored frozen until analysis.

The serum cholesterol, triacylglycerols, aspartate aminotransferase (AST) and alanine aminotransferase (ALT) were determined using commercial kits (BioVendor Ltd., Brno, Czech Republic). The total hepatic and faecal lipids were extracted with 2:1 chloroform-methanol and measured gravimetrically [14]. Hepatic cholesterol was saponified with $2 \mathrm{M}$ ethanolic $\mathrm{KOH}\left(1 \mathrm{~h}\right.$ at $\left.100{ }^{\circ} \mathrm{C}\right)$, extracted with ethyl ether, derivatised using trimethylchlorosilane and hexamethyldisilazane (Sigma-Aldrich, Prague, Czech Republic), and determined using gas chromatograph equipped with SAC-5 capillary column
Composition of control diet and experimental diets $(\mathrm{g} / \mathrm{kg})$

\begin{tabular}{l|c|c|c|c}
\hline \multirow{2}{*}{\multicolumn{1}{c}{ Ingredient }} & \multicolumn{4}{|c}{ Diet } \\
\cline { 2 - 5 } & $1^{\mathrm{a}}$ & $2^{\mathrm{a}}$ & 3 & 4 \\
\hline Cholesterol & 0 & 10 & 10 & 10 \\
Palm fat & 60 & 50 & 50 & 50 \\
Amidated alginate & 0 & 0 & 10 & 20 \\
Cellulose & 40 & 40 & 30 & 20 \\
Diet ST-1 $^{\mathrm{b}}$ & 900 & 900 & 900 & 900 \\
\hline
\end{tabular}

${ }^{\mathrm{a}}$ Control diets without amidated alginate. ${ }^{\mathrm{b}}$ The rat diet ST-1 ingredients were soybean meal, meat and bone meal, fish meal, wheat, maize, oats, wheat bran, limestone, dicalcium phosphate, salt, and supplements of vitamins, trace elements and amino acids. The diet contained crude protein, fibre, fat, ash and cholesterol at 196, 40, 24, 41 , and $0.28 \mathrm{~g} / \mathrm{kg}$.

(Supelco, Bellefonte, USA). The $5 \alpha$-cholestane at $0.5 \mathrm{mg} / \mathrm{ml}$ was used as the internal standard.

Faecal sterols were determined in freezedried samples chromatographically after butylation and silylation with Sylon HTP according to Batta et al. [15]. Norcholic acid was used as the internal standard. Gas chromatograph Focus - GC coupled with MS model ITQ 700 (Thermo Scientific, Illinois, 60060, USA) was used and equipped with the Thermo TR-5MS SQC column. Helium was the carrier gas. The neutral sterols and bile acids were identified on the basis of retention times by comparing to standards. The linear detector responses were confirmed for variable amounts of individual neutral sterols and bile acids injected onto the column. The dry matter (DM) of faeces was determined by oven drying the faeces at $105^{\circ} \mathrm{C}$.

The data were analysed by a one-way analysis of variance using the GLM procedure of SAS, version 8.2 (SAS Institute, Cary, NC, USA). The results were expressed as Means \pm SD. Significant differences $(P<0.05)$ were identified using Tukey's test. The Pearson correlation coefficient was used as a measure of the dependence between pairs of observations.

\section{Results and Discussion}

Body weight and feed intake did not differ among treatment groups (Fig. 1). Supplementation of diets with cholesterol significantly increased total serum cholesterol, hepatic fat, as well as cholesterol concentration in the liver tissue. In rats fed diets supplemented with cholesterol, amidated algi- 
nate significantly decreased serum cholesterol and hepatic cholesterol concentration. The serum total cholesterol and hepatic cholesterol were significantly correlated $(r=0.888 ; P<0.001)$. Amidated alginate at $20 \mathrm{~g} / \mathrm{kg}$ non-significantly increased activity of aminotransferases.

Amidated alginate at lower dosing $(10 \mathrm{~g} / \mathrm{kg}$ diet) significantly increased faecal output of fat, and at higher dosing $(20 \mathrm{~g} / \mathrm{kg}$ diet $)$ significantly decreased faecal output of bile acids (Fig. 2). Faecal output of bile acids significantly correlated with hepatic cholesterol $(r=0.791 ; P<0.001)$. In rats fed diets containing cholesterol serum cholesterol negatively correlated with the faecal output of cholesterol $(r=-0.496 ; P=0.022)$.

The hypocholesterolaemic effect of amidated alginate in rats fed cholesterol- and fat-enriched diets for 10 week was stable and similar to that observed in previous experiment in which amidated alginate was fed for three weeks [7]. The faecal output of cholesterol and serum cholesterol negatively correlated, which suggests that the faecal loss of cholesterol was important for the hypocholesterolemic effect of amidated alginate. Amidated alginate significantly decreased the faecal concentration of bile acids, presumably due to lower synthesis of bile acids in the liver in response to the lower availability of substrate cholesterol. The faecal output of bile acids and cholesterol concentration in hepatocytes were significantly correlated.

There were no significant signs of toxicity of amidated alginate (feed intake, weight of liver, activity of aminotransferases); however, the possibility of depletion of fat-soluble vitamins from the intestinal lumen at long-term treatment and high dosing of amidated alginate cannot be excluded.
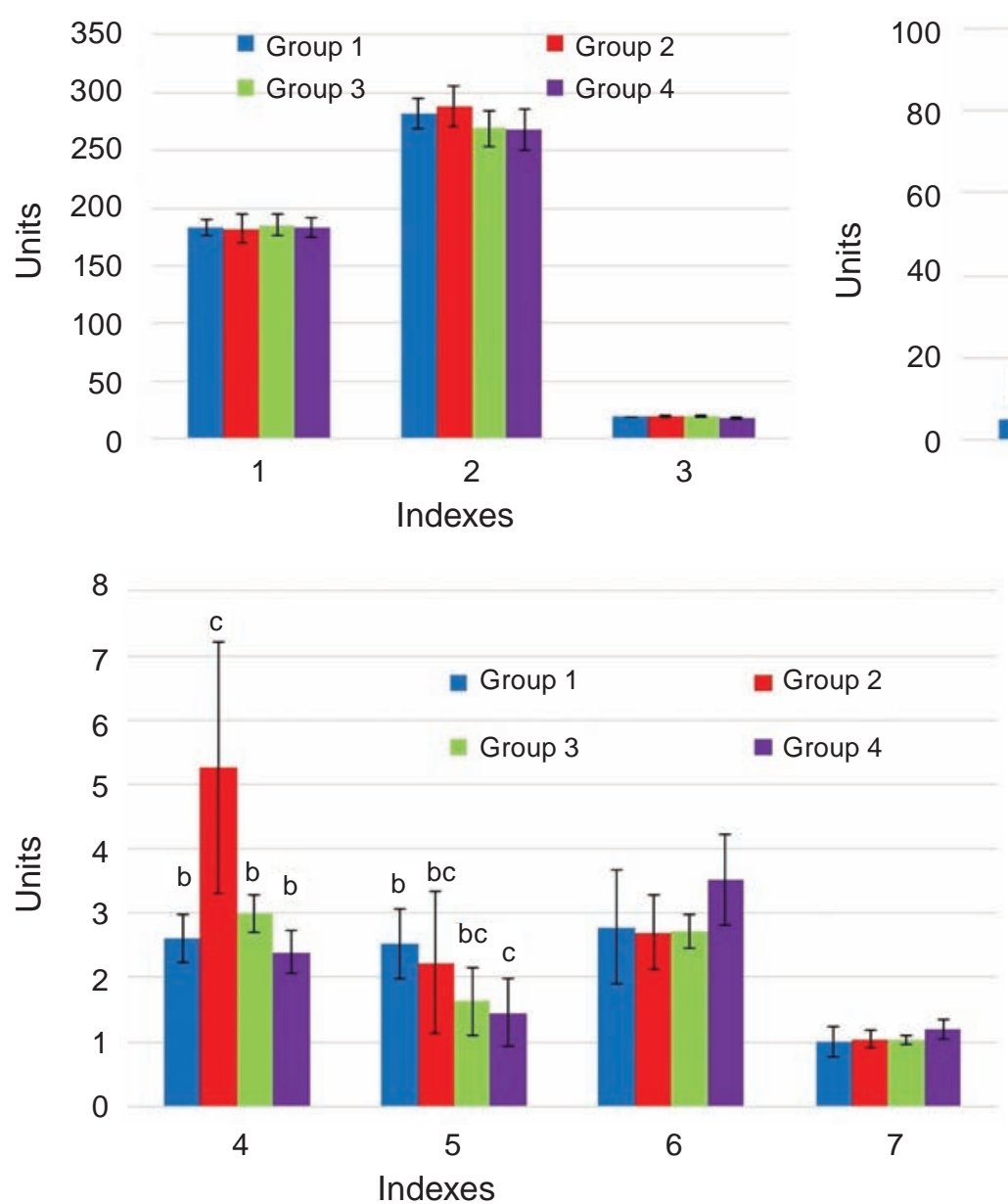

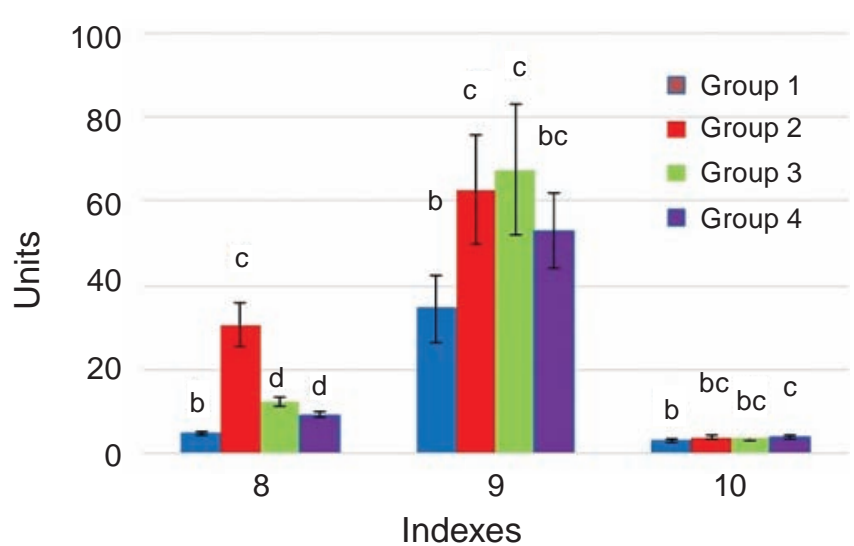

Indexes:

1 - Initial weight $(\mathrm{g})$

2 - Final weight $(\mathrm{g})$

3 - Feed intake (g/day)

Blood serum:

4 - Cholesterol ( $\mu \mathrm{mol} / \mathrm{ml})$

5 - Triacylglycerols $(\mu \mathrm{mol} / \mathrm{ml})$

6 - AST (nkat/ml)

7 - ALT (nkat/ml)

8 - Hepatic cholesterol $(\mu \mathrm{mol} / \mathrm{g})$

9 - Hepatic fat $(\mathrm{mg} / \mathrm{g})$

10 - Weght of liver ( $\mathrm{g} / 100 \mathrm{~g})$

Fig. 1. Effect of cholesterol and amidated alginate on growth, fed intake, serum and hepatic lipids, aminotransferases, and liver weight in rats ${ }^{a}$ (a Seven female rats per group. $\boldsymbol{b}$-d Values in the same index-set with different letters differ significantly) 


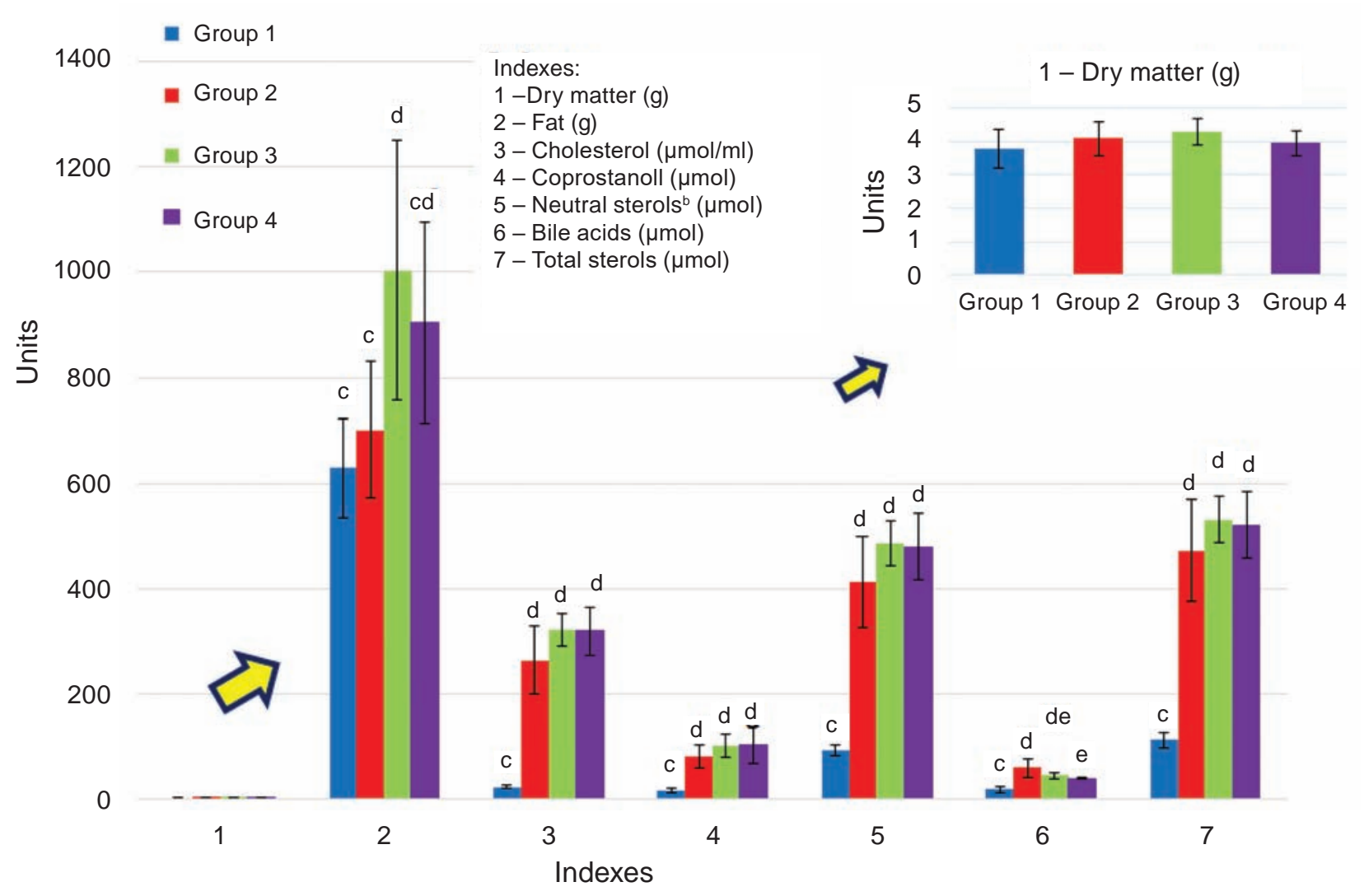

Fig. 2. Effect of cholesterol and amidated alginate on daily faecal output of dry matter, fat, and sterols in rats ${ }^{a}$ (a Seven female rats per group. $\boldsymbol{b}$ Including plant sterols. $\boldsymbol{c}$ - $\boldsymbol{e}$ Values in the same index-set with different letters differ significantly)

Acknowledgement. This work was supported by the Ministry of Agriculture of the Czech Republic (Project MZERO0714).

\section{ДОВГОСТРОКОВИЙ \\ ГІПОХОЛЕСТЕРИНЕМІЧНИЙ ЕФЕКТ АМІДОВАНОГО АЛЬГІНАТУ В ЩУРІВ}

М. Мароунек1, 3. Волек, Т. Таубнер 1 , Д. Душкова ${ }^{1}$ Л. Калачнюк ${ }^{2}$

${ }^{1}$ Інститут тваринництва, Прага, Чеська Республіка; e-mail: marounek.milan@vuzv.cz;

${ }^{2}$ Національний університет біоресурсів та природокористування України, Київ; e-mail: kalachnyuk_liliya@nubip.edu.ua; lilkalachnyuk@gmail.com

Вплив октадециламіду альгінової кислоти на холестерол сироватки крові й печінки, фекальне виділення жиру і стеролів було дослідже- но у самок щурів, яких утримували на раціонах, що містять холестерол і пальмовий жир відповідно по 10 і 50 г/кг маси тіла тварин протягом 10 тижнів. Амідований альгінат, який давали по 10 i 20 г/кг, значно зменшував рівень холестеролу в сироватці крові від 5,25 до 2,99 і 2,39 мкмоль/ мл та знижував рівень холестеролу в печінці від 30,7 до 12,3 і 9,4 мкмоль/г відповідно. Амідований альгінат збільшував фекальний вихід жиру і за вищої дози значно зменшував фекальний вихід жовчних кислот. Фекальне виділення жовчних кислот і холестеролу печінки вірогідно корелювало $(r=0,791, P<0,001)$. Результати експерименту показали, що гіпохолестеринемічний ефект амідованого альгінату зберігається впродовж 10 тижнів годування.

К л ю ч о в і с л о в а: холестерол, сироватка крові, печінка, фекалії, жири, жовчні кислоти. 


\section{ДОЛГОСРОЧНЫЙ \\ ГИПОХОЛЕСТЕРИНЕМИЧЕСКИЙ ЭФФЕКТ АМИДИРОВАННОГО АЛЬГИНАТА У КРЫС}

\author{
М. Мароунек ${ }^{1}$, 3.Волек ${ }^{1}$, T. Таубнер ${ }^{1}$, \\ Д. Душкова ${ }^{1}$ Л. Калачнюк \\ ${ }^{1}$ Институт животноводства, Прага, \\ Чешская Республика; \\ e-mail: marounek.milan@vuzv.cz \\ ${ }^{2}$ Национальний университет биоресурсов \\ и природопользования Украины, Киев; \\ e-mail: kalachnyuk_liliya@nubip.edu.ua; \\ lilkalachnyuk@gmail.com
}

Влияние октадециламида альгиновой кислоты на холестерол сыворотки крови и печени, фекальное выделение жира и стеролов было исследовано у самок крыс, которых содержали на рационах, содержащих холестерол и пальмовый жир соответственно по 10 и 50 г/кг массы тела животных в течение 10 недель. Амидированный альгинат (подаваемый по 10 и 20 г/кг) значительно уменьшал уровень холестерола в сыворотке крови от 5,25 до 2,99 и 2,39 мкмоль/мл и снижал уровень холестерола в печени от 30,7 до 12,3 и 9,4 мкмоль/г соответственно. Амидированный альгинат увеличивал фекальный выход жира и при более высокой дозе значительно уменьшал фекальный выход желчных кислот. Фекальное выделение желчных кислот и холестерола печени достоверно коррелировало $(r=0,791$, $P<0,001)$. Результаты настоящего эксперимента показали, что гипохолестеринемический эффект амидированного альгината сохраняется в течение 10 недель кормления.

К люче вы е с ло в а: холестерол, сыворотка крови, печень, фекалии, жиры, желчные кислоты.

\section{References}

1. Stedronsky ER. Interaction of bile acids and cholesterol with non-systemic agents having hypocholesterolemic properties. Biochim Biophys Acta. 1994; 1210(3): 255-287.

2. Ast M, Frishman WH. Bile acid sequestrants. J Clin Pharmacol. 1990; 30(2): 99-106.

3. Phan BA, Dayspring TD, Toth PP. Ezetimibe therapy: mechanism of action and clinical update. Vasc Health Risk Manag. 2012; 8: 415427.

4. Marounek M, Volek Z, Skřivanová E, Tůma J, Dušková D. Comparactive effect of amidated pectin and psyllium on cholesterol homeostasis in rats. Cent Eur J Biol. 2010; 5(3): 299-303.

5. Tůma J, Volek Z, Synytsya A, Dušková D, Marounek M. Hydrophobically modified celluloses as novel cholesterol-lowering polymers. Bioresources. 2014; 9(3): 4266-4273.

6. Marounek M, Volek Z, Tůma J, Duškova D., Kalachniuk M, Kalachnyuk L, Kalachnyuk G. Effect of exogenous cholesterol and amidated cellulose on fat and sterols concentration in faeces. Animal Biol. 2014; 16(3): 91-96.

7. Marounek M, Volek Z, Skřivanová E, Taubner T, Pebriansyah A, Dušková D. Comparative study of the hypocholesterolemic and hypolipidemic activity of alginate and amidated alginate in rats. Int J Biol Macromol. 2017; 105(Pt 1): 620-624.

8. Georg Jensen M, Pedersen C, Kristensen M, Frost G, Astrup A. Review: efficacy of alginate supplementation in relation to appetite regulation and metabolic risk factors: evidence from animal and human studies. Obes Rev. 2013; 14(2): 129144.

9. Matsui MS, Rozovski SJ. Drug-nutrient interaction. Clin Ther. 1982; 4(6): 423-440. 
10. Knodel LC, Talbert RL. Adverse effects of hypolipidaemic drugs. Med Toxicol. 1987; 2(1): 10-32.

11. Synytsya A, Čopíková J, Marounek M, Mlčochová P, Sihelníková L, Skoblya S, Havlátová $H$, Matějka $P$, Maryška $M$, Machovič V. N-octadecylpectinamide, a hydrophobic sorbent based on modification of highly methoxylated citrus pectin. Carbohydr Polym. 2004; 56(2): 169-179.

12. Taubner T, Marounek M, Synytsya A. Preparation and characterization of amidated derivatives of alginic acid. Int J Biol Macromol. 2017; 103: 202-207.
13. Spielmann J, Stangl GI, Eder K. Dietary pea protein stimulates bile acid excretion and lowers hepatic cholesterol concentration in rats. J Anim Physiol Anim Nutr (Berl). 2008; 92(6): 683-693.

14. Folch J, Lees M, Sloane Stanley GH. A simple method for the isolation and purification of total lipides from animal tissues. J Biol Chem. 1957; 226(1): 497-509.

15. Batta AK, Salen G, Batta P, Tint GS, Alberts DS, Earnest DL. Simultaneous quantitation of fatty acids, sterols and bile acids in human stool by capillary gas-liquid chromatography. J Chromatogr B Analyt Technol Biomed Life Sci. 2002; 775(2): 153-161.

Received 18.09.2018 